\title{
EXPLORING THE GOVERNANCE CHALLENGES ASSOCIATED WITH THE FAILED ATTEMPT TO DESIGNATE A NATIONAL PARK IN NORTHERN IRELAND
}

\author{
J.P.W. BELL \\ School of Planning Architecture and Civil Engineering, Queen's University Belfast, Northern Ireland.
}

\begin{abstract}
National parks are primarily designated for conservation purposes, yet globally they have become major economic generators through countryside tourism. Protected areas across Northern Ireland currently suffer from a management deficit and as a result natural landscapes in Northern Ireland are said to be degrading rapidly. The tourism industry in Northern Ireland relies heavily on the marketable potential of its natural heritage. Therefore, a predicted rise in tourist arrivals could accelerate environmental degradation, potentially jeopardising the future marketable value of countryside tourism. National park designation represents one possible mechanism for managing this tourism resource paradox. However, a recent attempt to proceed towards national park designation in Northern Ireland crystallises the complex governance challenges associated with designating national parks in multi-functional, privately owned and highly contested landscapes. The Mournes case study is drawn upon to highlight how local governance challenges represent a potential obstacle to securing widespread stakeholder support for the sustainability principles associated with contemporary national park models.

Keywords: environmental governance, national park, resource paradox, sustainable development.
\end{abstract}

\section{INTRODUCTION}

The need to harness the economic opportunities presented by tourism while avoiding the simultaneous destruction of precious landscapes is an important issue in Northern Ireland; national park designation potentially offers one mechanism for managing this impending paradox. This paper will first chart the emergence of sustainable development in a global context before examining its influence on protected area management in terms of widening the remit of protected areas to include people-orientated objectives. Second, the role of national parks as global economic generators will be discussed in the context of the 'resource paradox'. Focus will then revert to Northern Ireland. A review of government policy, which demonstrates economic-orientated governmental priorities, provides the backdrop for discussing the tourism resource paradox in Northern Ireland, a region heavily dependent on countryside tourism in its quest for economic growth. Semi-structured interviews undertaken with a broad range of stakeholders in one of Northern Ireland's candidate national parks, the Mourne Area of Outstanding Natural Beauty (AONB), provide the empirical grounding for discussing the governance challenges associated with designating national parks in Northern Ireland, potentially a prerequisite for more sustainable countryside management.

\section{SUSTAINABILITY AND CONSERVATION}

The most effective and widespread method for conserving nature and natural resources, to date, has involved setting aside 'protected areas' $[1,2]$ which currently occupy around $10 \%$ of the earth's land surface [3]. The World Conservation Union (IUCN) has defined a protected area as 'a clearly defined geographical space, recognised, dedicated and managed, through legal or other effective means, to achieve the long-term conservation of nature with associated ecosystem services and cultural values' [3]. National parks represent one category of protected area and have 'long been seen as jewels in the crown of nature conservation' [4]. However, the principle of designating protected areas is often perceived to reflect regional, national and particularly international needs at the expense of local 
needs, resulting in local frustrations stemming from what are perceived to be 'externally imposed priorities' [5]. As a consequence, some rural communities have traditionally viewed pronouncements regarding national park designation as the 'voice of doom' [6]. However, others argue that management of natural areas has changed significantly from the strictly protectionist, 'keep people out mentality' referred to as 'fortress conservation' [7, 8] towards a 'new conservation' which integrates conservation with socio-economic factors [9]. This broader conservation agenda has been fashioned by a number of global international movements. Since the first World Conservation Strategy (1980) and publication of Our Common Future [10] followed by the Fourth Congress on National Parks (1992), it has been recognised within the environmental community that environmental protection should be integrated with socio-economic, cultural and political considerations [11] both within and outside the protected area. The Brundtland Report (1987) recognised the importance of public involvement in policy and practice if sustainable development was to be achieved:

'The law cannot enforce the common interest. It principally needs community knowledge and support, which entails greater public participation in the decisions which affect the environment. This is best achieved by decentralising the management of resources upon which local communities depend and giving these communities an effective say over the use of resources. It will also require promoting citizens' initiatives, empowering people's organisations, and strengthening local democracy' [10].

The importance of public participation was reflected at the Rio Earth Summit (1992) which further challenged the strictly protectionist model of conservation through Local Agenda 21 [12], which emphasised the importance of incorporating new bottom-up forms of participation and involvement of citizens, communities and NGO's in resolving potential conflicts between the environment and development $[7,13]$.

\section{THE BROADENING PURPOSES OF PROTECTED AREA MANAGEMENT}

The global emergence of sustainable development as the guiding rudder of international development is reflected in protected area management by the broadening of IUCN designations to include category $\mathrm{V}$ designations [11, 14]. The increased importance of 'landscape' as a management category [15] has been underpinned by a theoretical shift in western Europe from 'land protection' towards establishing 'protected landscapes'. Beresford and Phillips [16] describe protected landscapes as 'lived in, working landscapes, subject to a particular conservation regime' (p. 23). Phillips [17] identified two key reasons for the growing recognition of protected landscapes; first, the realisation that pursuing conservation objectives alone within parks or reserves is not feasible and second the growing acknowledgement of the importance of involving local people residing within or outside protected area boundaries in the management of protected areas. Protected landscapes have become a dominant paradigm through which the highly humanised and inhabited landscapes of Europe are now managed [15] encompassing a broader set of management objectives beyond the pure conservation or strict preservation approach. Category $\mathrm{V}$ designations require a management approach which incorporates social, economic and cultural interests and are therefore suitable for multi-functional landscapes which possess a mosaic of interest groups. Furthermore, category $\mathrm{V}$ designations are particularly attractive for many countries as they offer a mechanism for contributing to the realisation of sustainable development objectives. Many countries still classify their category $\mathrm{V}$ designations as 'national parks' which has resulted in the establishment of national parks in richly inhabited areas where strict conservation goals are potentially compromised by socio-economic and cultural considerations. These category V landscapes contrast sharply with the areas of pristine wilderness where national parks were first designated in the United States. With the exception of Scandinavia, the strictly environmental protectionist approach (espoused 
in the United States) was not easily applied to the humanised and cultivated landscapes of Europe [18]. Therefore, European national parks take many forms and are built around managing a broader range of management objectives. Just as the purposes of protected area management have expanded, national park purposes have evolved to the extent that they are increasingly viewed as mechanisms for delivering sustainable development goals. For example, the National Parks (Scotland) Act 2000, which enabled the designation of national parks in Scotland for the first time (Loch Lomond and Trossachs (2002) and Cairngorms (2003)), was based around the principles of sustainable development [10]. The Act explicitly includes an additional national park aim that is 'to promote sustainable economic and social development of the area's communities' [19].

\section{NATIONAL PARKS AS ECONOMIC GENERATORS - IMPLICATIONS FOR SUSTAINABILITY}

While fulfilling their primary aim to conserve areas of environmental significance, protected areas can provide a marketable commodity in rural areas through tourism. Although national parks were traditionally designated to primarily enhance environmental protection, models of national parks have evolved to incorporate, to varying degrees, social and economic interests. Even from their inception in the United States, national parks were recognised for their vast tourism potential [20,21]. Olmsted posed this vital question as far back as 1865; 'how to admit all the visitors who wish to come without destroying the very thing they value?' [22] According to Spirn [22], this question remains largely unresolved today. Indeed, at the other end of the spectrum strict, protection too remains to be resolved. Many national parks have since become key economic generators through growth of the nature-based tourism industry [6, 23]. McCool [24] gave little support to the belief that designating areas lead to a rise in visits, whereas a more recent study by Fredman et al. [25] found a $40 \%$ increase in visitation levels following National Park designation in Sweden. Commodification of nature [26-28], which views natural resource usage through a lens of economic exploitation, could be contradictory to the traditional concept of designating protected areas in the first place. Such a traditional view of national parks often ignores the importance of the cultural rural landscape and the importance of the local population. The trend of utilising protected areas as economic tools is evident across the world [4, 26, 27, 29]. In light of the potential financial spin-offs associated with national park designation, balancing the interests of socio-economic development with environmental protection has become a major challenge for management of protected areas worldwide. These dilemmas can be conceptualised through the 'resource paradox' [30-32] which relates to the use versus overuse scenario; natural areas offer a resource to be marketed, yet overuse (potentially through tourism) could destroy the natural beauty upon which the tourist experience depends, thereby jeopardising future tourism. Just as issues have been raised regarding the oxymoronic nature of the term sustainable development $[33,34]$, similar contradictions emerge in the context of managing diverse and potentially irreconcilable interests within protected areas.

\section{THE NORTHERN IRISH CONTEXT}

Despite numerous attempts, no national parks have been designated in Northern Ireland. In response to countryside pressures, the Ulster Countryside report, written by the Northern Ireland Planning Advisory Board (1947), 'unanimously and urgently recommend(ed) that some areas be scheduled as National Parks' [35]. Failure to designate national parks in Northern Ireland since then can be attributed to, among other issues, strong landowner opposition and alternative political priorities (dealing with civil unrest) [36]. Recent attempts to designate the Mourne area stalled because of political hesitation in the face of local landowner objection and a heavily criticised public consultation [37-39]. Outdated primary legislation still exists to designate national parks in Northern Ireland 
(initially via the Amenity Land Act (NI) 1965 and more recently through the Amenity Lands Order (NI) 1985), but there is no provision for powers or mechanisms for national park management.

While civil unrest contributed to environmental neglect in Northern Ireland [36], the prolonged violence and political instability also had a clear economic impact on the region [40]. On emerging from four decades of sectarian conflict, the Northern Ireland Programme for Government [41] has identified 'growing the economy' (p. 2) as its top priority and outlined the importance of identifying ways of maximising the value of currently existing assets in Northern Ireland [41]. Due to 30 years of underinvestment, tourism has the potential to grow faster in Northern Ireland than elsewhere in the United Kingdom [42]. Accordingly, tourism has been identified as an undeveloped economic sector and ear marked as a major new growth industry with government aiming to double tourism revenue by 2020 through increasing visitor numbers from 3.2 million to 4.5 million [42]. Indeed, a discussion paper produced by the Environmental Policy Group (2004) recognised the dependence of the Northern Irish tourism industry on countryside areas and particularly the major tourist destinations which lie inside areas currently designated as AONBs: 'tourism in Northern Ireland depends largely on the quality of the countryside, its natural attractions and its distinctive cultural heritage and many visitor destinations are within AONB's' [43]. Given that the tourism industry in Northern Ireland is heavily dependent on natural heritage, the potential for tourism induced destruction of natural resources is heightened; this conundrum is conceptualised through the 'resource paradox' and is referred to in a publication of the Environmental Policy Group (NI): 'National Park designation may help retain the landscape quality required to attract tourism and may increase visitor numbers to designated areas, as national parks are often a 'must see' destination' [43].

It is questionable whether increasing visitor numbers is compatible with retaining landscape quality. It makes sense, from an economic and environmental perspective, to protect these areas against unsustainable tourism-related pressure. Currently, AONBs represent the highest level of landscape protection in Northern Ireland. AONB management bodies in Northern Ireland have no statutory management powers, so it is questionable whether protected areas are being afforded adequate landscape protection and whether sufficient funding is available to manage these natural resources [44]. The Mourne Heritage Trust, the body responsible for managing the Mourne mountains, has expressed concerns regarding their ability to manage the rapidly deteriorating Mourne environment on diminishing resources [38]. While the label of a national park has the potential to attract unsustainable tourist numbers $[6,23]$, it could also provide structures and mechanisms to actively manage tourism and safeguard natural resources. National parks potentially offer one mechanism for managing or exacerbating this potential 'resource paradox'.

There is a delicate balance to be struck between enhancing/protecting the natural environment and maximising the opportunities presented by new rural economies such as tourism. While stakeholders often hold differing views of how environmental resources should be used, stakeholder priorities generally fall within and across three broad categories; social, economic and environmental interests. Within these categories, further division can develop between different scales of interest, for example, the challenge of catering for 'local' and/or 'national' priorities [45]. Therefore multipurpose management within deeply contested protected areas could ultimately be viewed as a sustainability challenge based on managing the tensions between the three principles of sustainability. National parks represent one mechanism for managing the impending tourism resource paradox in Northern Ireland. The following section will trace the historical emergence of national parks in Northern Ireland and the remainder of the paper will draw on interview findings and analysis of secondary documents to discuss the governance challenges associated with designating national parks in Northern Ireland and the prospects of providing a long-term management solution to the tourism resource paradox. 


\section{THE MOURNE CASE STUDY}

\subsection{The Mournes}

This case study provides a brief description of the Mourne landscape before demonstrating the multi-functional and highly contested nature of the Mournes. The current administrative and management arrangements in the Mournes will be referred to before charting the re-emergence of discussions regarding the possibility of designating a 'national park' in the Mournes. A range of local stakeholder perspectives will subsequently be drawn upon to illustrate the multiple understandings of the potential impacts of a Mourne national park, followed by a critical analysis of the governance challenges which arose during the Mourne national park consultation process. Finally, in addition to a number of wider considerations, the prospects of enhanced protected area management in Northern Ireland will be discussed in the context of the latest attempt to proceed towards a national park designation in the Mournes.

\subsubsection{An internationally significant area}

Weather, geology and human activity have interacted to create a unique mosaic of landscapes constituting the Mournes, which at its heart contains a ring of 12 peaks, each in excess of $600 \mathrm{~m}$. Sweeping down from a granite massif through upland heath, forest, blanket bog and farmland to the maritime environment of the sandy estuary, the Mournes support a diverse range of flora and fauna [46]. The endangered peregrine falcon, red grouse, alpine clubmoss and red squirrel are all sustained within the rich tapestry of Mourne landscapes [46]. Owing to its rich natural heritage, Mourne boasts numerous International, National and European designations, including Ireland's first National Nature Reserve at Murlough Bay. An area covering approximately $570 \mathrm{~km}^{2}$ was designated as an AONB in 1965 and re-designated in 1986. The Mourne AONB straddles three district Council areas; around $75 \%$ of which falls within the Newry and Mourne District Council area; $15 \%$ within the Down District Council area; and 10\% within the Banbridge District Council area [47]. In addition to biodiversity, the area has a rich legacy of human settlement etched indelibly across the landscape. A plethora of dry stone walls, stone cottages and small farm holdings feature prominently on the Mourne landscape. Crucially, 50,000 people still reside within the Mourne and Slieve Croob area occupying a number of small- and medium-sized settlements and a sizeable proportion of dispersed rural dwellings [48]. A number of coastal and rural settlements, including tourism-orientated settlements such as Newcastle and fishing villages, such as Kilkeel, are situated within the Mourne AONB. Meanwhile there is a varied ownership pattern; Mourne Trustees, alongside the Water Service, the Forest Service and the National Trust own large tracts of the High Mournes, while the entire area of the Mournes consists of over 1,500 private farmers or landowners.

\subsubsection{The many faces of the Mournes}

This varied landscape has acquired different land uses as a result of the economic, environmental and social forces impacting on the area. While continuing to sustain traditional economies and industries, such as agriculture (53\% of the land is actively farmed with an average farm holding size of 15 ha [49]), fishing, forestry and small-scale quarrying, the Mournes also have a distinct recreational legacy. Indeed, social and community issues represent another influential force within the Mourne AONB as the area supports a significant number of settlements and dispersed rural communities. The Mournes, readily accessible from both Dublin and Belfast, have become a primary tourist destination in Northern Ireland, with approximately 150,000 visitors per annum [50]. The significance of the Mournes to the tourism industry was recognised by the Northern Ireland Tourist 
Board (NITB) which selected the Mournes as one of five signature projects. Tourism is now an economic cornerstone for the Mourne area contributing significantly to local employment and business revenue [50]. However, Mourne has a fragile rural economy given the dependence on declining farm incomes [51] and seasonal tourism-related employment.

The multi-functional dimension of the Mournes, comprising distinct social, economic and environmental functions, combined with the peculiar ownership pattern, creates a highly complex and contested terrain. The challenges of accommodating diverse and often competing interests surfaced during recent national park discussions (see section 6.4). Speculative building, commercial enterprises, such as quarrying and tourism, are placing a significant burden on the Mourne landscape through erosion, disturbance of wildlife, congestion and litter [46]. It has been recognised that 'a sustainable approach to the development of tourism in the area needs to be established to manage these (tourism related) impacts' [46]. With an apparent management deficit in the Mournes [38] the prospect of increased tourist numbers represents a potential threat to its environmental integrity. It is questionable whether the Mourne Heritage Trust is capable of providing the integrated and proactive management to sustainably handle current let alone increased visitor levels. The structures and management arrangements associated with national parks represent one option for better-managing tourism pressures. However, distaste for the current (low) levels of management in the Mournes came across strongly during interviews with local stakeholders. Enhancing management in Mourne, through national park designation, is therefore unlikely to gain widespread landowner support. The prospects of overcoming such governance challenges will now be referred to in the context of recent attempts to proceed towards the introduction of a national park in the Mournes.

\subsection{Reopening the national park debate in Mourne}

A report (conducted by Europarc [52]) commissioned by the Environment and Heritage Service in 2002 (EHS, now the Northern Ireland Environment Agency, NIEA) concluded that the Mournes represented the most appropriate location for a national park in Northern Ireland [53]. On this basis the then Minister for the Environment in the Northern Ireland Executive, Dermot Nesbitt, declared his intention to establish a national park in the Mournes [54, 55]. Nesbitt, recognising the importance of immediate action said: 'we must act now to ensure that they (Northern Ireland's finest landscapes) are properly conserved for the benefit and enjoyment of present and future generations' [53] established a body to develop a framework for designation. Nesbitt also acknowledged that, 'most importantly'....the body 'will consult local interests to ensure that the proposals have widespread support' [54]. Following the temporary suspension of the Northern Ireland Assembly (on 11 February 2000), Direct Rule Minister for the Environment, Angela Smith, affirmed her support for progressing towards designating a Mourne national park: 'I intend to progress the work set in train by the devolved administration to establish Northern Ireland's first national park in the Mournes' [55]. While acknowledging that the views of local people would carry significant weight in reaching a final decision, the intentions of both ministers indicated a clear preference for the Mournes to become Northern Ireland's first national park. The first line of a national park-related leaflet produced by the Environment and Heritage Service [56] stated; 'it is vital that we get the designation of our first national park right' (p. 1). This suggests that at the time there was a clear government stance in favour of introducing national parks in Northern Ireland.

Angela Smith demonstrated her commitment to a Mourne national park by publishing a discussion paper to seek the views of the general public and to inform the drafting of proposals for new national park legislation. Smith simultaneously established an independent body in October 2004 - the Mourne National Park Working Party (MNPWP) - comprising representatives from a range 
of organisations and interest groups. The Working Party was asked by government to commission research examining possible national park boundaries, to develop proposals regarding the possible management structure and conduct a formal consultation before reporting back to the minister. The Working Party was responsible for 'representing the views of the people of Mourne' [48]. This proved to be no easy task given the multitude of interests within the contested and multifunctional Mourne landscape. Significantly, the consultation was launched within a legislative vacuum, whereby outdated primary legislation had yet to be replaced by new primary and secondary legislation. The purpose of the MNPWP consultation was clearly not to gauge levels of support for a national park by conducting a referendum style 'yes' or 'no' national park consultation [48], but rather to 'open up the debate' (p. 13) through a process of engaging with and informing the public as well as hearing views on a proposed national park boundary and the possible impacts of designation.

\subsection{The MNPWP consultation}

Furnished with the findings from various consultants' reports and a possible boundary, the MNPWP launched a formal consultation on 1 September 2006 lasting until 31 January 2007. The exercise, which received significant media attention, was targeted specifically at the local Mourne population and particular stakeholder groupings and therefore did not constitute a Northern Ireland-wide consultation. After distributing 42,000 leaflets, creating a website and telephone information line, the consultation comprised a series of public meetings and specific sector meetings whereby members of the working party were available to discuss issues raised. A mobile information unit was also commissioned to visit towns and villages in the Mourne area, giving further opportunity for local people to voice their opinions [48]. Meanwhile, specific stakeholder groups were given the opportunity to meet and discuss their concerns with individual members of the working party [57]. Over 1,150 people attended the 10 public consultation events, 79 written submissions were received and 3 petitions submitted. The findings from these information-gathering processes culminated in the working party's Report to the Minister [48] which was submitted in September 2007, comprising 29 core recommendations.

\subsection{The challenges of negotiating multiple stakeholder perspectives}

A spectrum of interviewee responses have been drawn upon to illustrate stakeholder perceptions regarding the impact that national park designation could have on a number of key issues. Each of these issues represents a specific environmental, economic or social interest within the Mournes and therefore has direct relevance to fulfilling sustainable development objectives. The table below gives a flavour of the contrasting opinions. These issues are not unique to Mourne, but rather are typical of many rural areas and national parks across the United Kingdom.

From right to left there is an obvious split between landowners/farming lobby and conservationorientated stakeholder. The latter refers to members of the conservation lobby who requested that their identities remain anonymous. With regard to anti-social problems/environmental pressure the local council representative and the conservation-orientated stakeholder believed that a national park would bring the necessary structures and enhanced rangering service to better manage pressure emanating from tourism (tourism resource paradox), whereas the farming lobby is unconvinced. In relation to the impact on farming practices, the council and the conservation stakeholder referred to the Department for Regional Development (NI) which had gone on record as saying there will be no additional restrictions, whereas the farming community still fear a national park would create a 
'living museum' (interview with farming representative) or 'land frozen in time' (interview with Mourne trustee).

Restriction on development opportunities is a particularly thorny issue in Northern Ireland. The desire to sell land for housing has stemmed from a traditionally unrestrictive rural housing policy throughout Ireland. In 2005, rural planning approvals for single dwellings was three times that of England, Wales and Scotland combined [58]. There was collective agreement among those interviewed that the unsustainable one-off housing epidemic should be confined to the past. As one local politician explained: 'The figures here leading up to 2007 [were] just astonishing, we were destroying the countryside and you will see now a load of places they have put in foundations to keep the planning approval ... .not only do you have what has been built, but it's even more frightening to see what has been approved but not built yet because of the recession'. In 2006, more restrictive rural planning policy (draft PPS14) was introduced by Direct rule Minister Jeff Rooker issuing a presumption against development in the countryside. The draft policy proved particularly controversial and many local politicians united behind the farming community in their campaign to have the policy scrapped [58]. Interestingly, one interviewee commented on how the PPS14 debacle had undermined the Mourne national park consultation which was undertaken around a similar time. The local conservationist commented:

The fact that it (the Mourne national park consultation) coincided with PPS14....people mixed the two things up and they saw this as being, well look what Rooker's just done with PPS14, he's closed down the countryside for building; so a national park would be even worse.

Furthermore, following the reinstatement of devolved powers in 2007, draft PPS14 was abandoned in favour of a more balanced rural planning policy (PPS21) giving greater consideration to local socio-economic needs. The conservation lobby, in particular, regard the loopholes associated with PPS21 as paving the way for an imminent return to a building free for all [59]. This illustrates the dilemma of supposedly more democratic devolved policy making, having potentially detrimental environmental consequences. Indeed, one conservation NGO representative stated: 'Direct rule Ministers were freer to express themselves more favourably towards the countryside.' Meanwhile one political representative commented: 'environmental protection has taken a step backwards under devolution'. Stakeholders interviewed were satisfied that PPS21 provided a more restrictive approach than bygone years, while continuing to facilitate sustainable social and economic development. However, a Mourne national park accompanied by more restrictive planning policy is likely to prove particularly controversial within the landowning community in Mourne. PPS21 makes a number of allowances to sustain rural communities. For example, the policy states that a new farm dwelling will be permitted every 10 years. In light of such concessions, additional regulations would likely be required if a Mourne 'national park' is to fulfil its overall purpose which, even within a sustainable development model giving considerable weight to socio-economic considerations, should still be principally concerned with countryside protection. In a region with a legacy of predominantly unrestrictive rural housing policy, such regulations are likely to be alien and therefore highly contested. Many believe that national park opposition is tied up in fear over potential restrictions on rural house building and a concern that national park designation would end the development of single houses in the countryside 'once and for all': 'One of their [landowners] major fears was that bungalow blight, would be slapped down. Currently, any farmer who gets into financial trouble just sells a site ... it was a financial situation ... their economic survival is linked in with the planning situation [a national park would mean] they had no parachute, no life raft' (interview with community representative). This very real fear was acknowledged by one local farming representative who described selling land for housing as a vital lifeline for many within the farming community: '[T]here's that little money in farming, people were actually farming houses for to keep their 
Table 1: Stakeholder understandings of the potential effect of national park designation on a number of key issues.

\begin{tabular}{|c|c|c|c|c|}
\hline Topic & $\begin{array}{l}\text { Conservation- } \\
\text { orientated } \\
\text { stakeholder }\end{array}$ & $\begin{array}{l}\text { Council } \\
\text { representative }\end{array}$ & $\begin{array}{l}\text { Mourne } \\
\text { Trustee }\end{array}$ & $\begin{array}{l}\text { Farming } \\
\text { representative }\end{array}$ \\
\hline $\begin{array}{l}\text { Unsustainable } \\
\text { environmental } \\
\text { pressure }\end{array}$ & $\begin{array}{l}\text { Enhanced man- } \\
\text { agement structure } \\
\text { to manage this } \\
\text { threat }\end{array}$ & $\begin{array}{l}\text { Enhanced } \\
\text { management struc- } \\
\text { ture to manage this } \\
\text { threat }\end{array}$ & $\begin{array}{l}\text { Trustees should be } \\
\text { empowered; } \\
\text { no need for a } \\
\text { management } \\
\text { authority }\end{array}$ & $\begin{array}{l}\text { Biodiversity } \\
\text { affected by } \\
\text { designation - } \\
\text { unsustainable } \\
\text { visitor numbers }\end{array}$ \\
\hline $\begin{array}{l}\text { Farming } \\
\text { vulnerability }\end{array}$ & $\begin{array}{l}\text { No additional } \\
\text { restrictions/ } \\
\text { diversification } \\
\text { opportunities }\end{array}$ & $\begin{array}{l}\text { No additional } \\
\text { restrictions/diversifi- } \\
\text { cation opportunities }\end{array}$ & $\begin{array}{l}\text { Farming practices } \\
\text { will be limited }\end{array}$ & $\begin{array}{l}\text { Fossilise the farm- } \\
\text { ing industry/do not } \\
\text { need national park } \\
\text { to diversify }\end{array}$ \\
\hline Employment & $\begin{array}{l}\text { Job provision } \\
\text { across a variety } \\
\text { of sectors }\end{array}$ & $\begin{array}{l}\text { Increased job } \\
\text { opportunities }\end{array}$ & $\begin{array}{l}\text { Few quality jobs, } \\
\text { only part-time }\end{array}$ & $\begin{array}{l}\text { Not enough jobs } \\
\text { to justify a national } \\
\text { park }\end{array}$ \\
\hline $\begin{array}{l}\text { Development } \\
\text { opportunities }\end{array}$ & $\begin{array}{l}\text { Shift in rural } \\
\text { planning policy } \\
\text { anyway - PPS } 21\end{array}$ & $\begin{array}{l}\text { Shift in rural } \\
\text { planning policy } \\
\text { anyway - PPS } 21\end{array}$ & $\begin{array}{l}\text { Mournes to become } \\
\text { a 'land frozen in } \\
\text { time' }\end{array}$ & $\begin{array}{l}\text { Mournes to } \\
\text { become 'living } \\
\text { museum' }\end{array}$ \\
\hline $\begin{array}{l}\text { Housing } \\
\text { affordability }\end{array}$ & $\begin{array}{l}\text { Recognised } \\
\text { affordability } \\
\text { already an issue: } \\
\text { national park a } \\
\text { potential solution }\end{array}$ & $\begin{array}{l}\text { The problem of } \\
\text { affordability } \\
\text { exacerbated }\end{array}$ & $\begin{array}{l}\text { Houses already } \\
\text { unaffordable will } \\
\text { make no difference }\end{array}$ & $\begin{array}{l}\text { House prices will } \\
\text { soar forcing young } \\
\text { people out }\end{array}$ \\
\hline $\begin{array}{l}\text { Social } \\
\text { problems }\end{array}$ & $\begin{array}{l}\text { Enhanced } \\
\text { rangering service }\end{array}$ & $\begin{array}{l}\text { Enhanced } \\
\text { rangering service }\end{array}$ & $\begin{array}{l}\text { National Park users } \\
\text { would not create } \\
\text { these problems }\end{array}$ & $\begin{array}{l}\text { Rangers would } \\
\text { make no difference }\end{array}$ \\
\hline
\end{tabular}

businesses running and that can't last forever. If we were able to get money in from other sources without having to sell land, we'd be a hell of a lot better off'. Meanwhile, another Mourne resident observed: 'This was one of their fears [a restrictive national park], where's our life raft you know it's another titanic'. Restrictions on rural housing can therefore be directly linked to landowner concerns that the national park area would become a 'living museum' or 'land frozen in time' (see Table 1) where development is strictly prohibited.

The impact of a Mourne national park on the area's employment structure was keenly debated. At one end of the spectrum the management body representative suggested national park designation would provide full-time and part-time employment opportunities across a number of sectors, while at the other end of the spectrum a Mourne Trustee felt additional employment opportunities would be minimal with a handful of part-time tourism-related jobs at best. All stakeholders recognised the problems associated with housing affordability in Mourne. A Mourne Trustee recognised that houses are already unaffordable and a national park designation would have negligible impact on young people's ability to afford a home in the area. Conversely, it was suggested by other interviewees that a national park could specifically challenge affordability through implementing affordable housing 
schemes. The environmental and landowning/farming community appear to have opposing views on the potential implications of a Mourne national park.

\subsection{Critiquing the consultative process}

While these initial interview responses demonstrate the divergence in opinion among stakeholders, the flawed consultation process potentially exacerbated division. This highlights the scale of the governance challenges associated with designating national parks within typically heterogeneous and contested landscapes found in Northern Ireland. The consultation also demonstrates the dilemma that sustainability entails in terms of reconciling competing and often contradictory stakeholder interests. In their report, the working party recognised a number of weaknesses associated with the consultation process and subsequent commentators have identified numerous shortcomings. This section will first outline the core weaknesses of the consultation as identified in the working party report, before drawing on some wider literature and further interview responses to explore aspects of this criticism in more detail [60].

The first criticism acknowledged by the working party relates to 'coverage'. The working party notes that criticism was directed at the fact consultation meetings were limited to particular areas [48]. It was felt that the working party should have been allowed to consult across Northern Ireland and that the mobile information unit should have been allowed to tour outside of the Mourne area. This issue has resonance with a key debate in environmental management regarding the extent to which regional or national interests should be considered within protected area management [48]. In this instance, the Mourne national park debate was confined solely to the Mournes locality. A Northern Ireland-wide consultation was therefore outside the remit of the working party, which appears to have been somewhat constrained by both time and money [38]. These limitations could have had a direct impact on the operational effectiveness of the working party and is an issue that would need to be addressed when considering any future consultations.

The second criticism acknowledged by the working party relates to the format adopted during the consultative meetings. It was recognised that 'the meeting format did not facilitate the expression of a range of views' [48] with one interviewee describing the public meetings as 'farcical'. A further interviewee described how he felt 'rail roaded to an extent that no matter what you said they were shouting and opposing it you know, but you didn't get a fair crack of the whip ... a lot of the open meetings were commandeered by the farming community'. Some stakeholders perceived the traditional top table meeting format of experts answering to a crowd as inappropriate and instead a surgery, drop-in style approach would have been preferred (interview with Mr David Fox). Indeed, all stakeholders interviewed appeared to voice dismay at the way in which the consultation meetings were conducted. Disruptive behaviour, a lack of respect towards differing views and an absence of meaningful dialogue are some of the factors which mired the meetings [37-39]. A particularly "strong and vocal "no" campaign' [48] was evident throughout the process, mainly directed by an element of the local farming community. Notably, support for the working party from the local farming community was eroded following a radio interview with the chairman of the working party which created a perception within the farming community that the chairman was favourable towards the idea of national park [37]. In combination with the series of ministerial position statements, referred to in section 6.2, this created a feeling that a Mourne national park was a 'done deal' $[38,48]$. While some have labelled the vociferous 'no' campaign as constituting an unrepresentative section of the farming community [39] opinion was split between interviewees regarding the true extent of the opposition to a national park. One interviewee commented: "the pro voice is stronger than the no voice in numbers but the tactics that the no vote uses has got them a bigger representation than 
I think they're worth' Regardless of the true extent of the opposition, the strength of the 'no' campaign and the powerful position they adopted had stark ramifications for the entire consultation process. Meaningful engagement with the farming community was limited and the 'no' campaigners showed reluctance to engage in the consultation meetings. Their actions appeared to have an intimidatory effect on other sections of the community. For example, interviewees reported threats to boycott businesses if chambers of commerce supported a national park, and members of the working party and other local representatives were challenged somewhat aggressively in the course of their day-to-day business. Claire Maxwell, a local business woman commented: 'I felt intimidated by the other side and I had received phone calls and things like that telling me to change my mind, what am I talking about; things like that you know'. Meanwhile, it was felt by two stakeholders that there was a paucity of ordinary people involved in the consultation process; that the moderate voice of 'people who weren't so zealous that they wanted to go to a meeting and shout the odds and they weren't so much in favour that they felt the need to stand up for the idea. They're just you know they're the people walking up and down the street ... who weren't really heard' (Mr David Fox). A lack of engagement with the general public could have stemmed from a widespread perception within the local community that 'this issue doesn't affect me' and a belief that this was a battle between conservationists and landowners (interview NGO representative). Indeed, one member of the working party explained how a member of the public commented on how they thought the public meetings were for landowners only.

McAreavey [38] refers to the power differentials in a somewhat different context to those intercommunal power relations as evidenced above. McAreavey [38] recognises the particularly influence of the government who administered the consultation through a superimposed body (the working party); a rather different but equally salient factor which had a similar impact in terms of constraining certain individuals within the consultation process. One interviewee commented that 'farmers are conservative and they don't like change ... people don't like groups who turn up to organise you, that's why there is such incredible widespread dislike for the Mourne Heritage Trust' (Mr Gareth McGrath) while another interviewee compared the dominant voices within the Mourne Working Party consultation, to the Tea Party activists in America describing them as 'the very reactionary right wing of both sides of our community; the Nationalists and the Unionists, the very anti-change sort of brigade' (Mr Richard McLaughlin). The latter suggested that much of the opposition to the national park proposal came from rather conservative elements of the community who tend to take a strong ideological or gut reaction against government-led or collective initiatives, to the point of resisting something almost for the sake of it or in a self-interested fashion. This anti-government sentiment which came across in a number of subsequent interviews may explain the apparent disdain for the idea of being 'managed' or introducing enhanced management in the Mournes (as suggested by Mr Gareth McGrath), through what are perceived to be externally imposed management arrangements. While certain individuals and stakeholder groupings acquired more dominant positions and exerted their influence within the local community (an example of horizontal or inter-communal power differentials), this power was seemingly mobilised in response to the unreasonable way in which the Mourne national park idea was initiated and pursued (vertical power) by government. The vociferous and dominating nature of the anti-national park voice which contributed to suppressing widespread public involvement appears to have been a reaction to the way government initiated and conducted the process. The actions of government appear to have fuelled a long-standing distaste towards government and from an early stage the consultation was seen as another example of government wielding an inappropriate level of influence.

A third key criticism of the consultation process again relating to the consultation meetings was that meetings offered little in the way of information or answers to questions posed [37, 38, 48]. However, it appears that different stakeholder understandings of the purpose of the consultation 


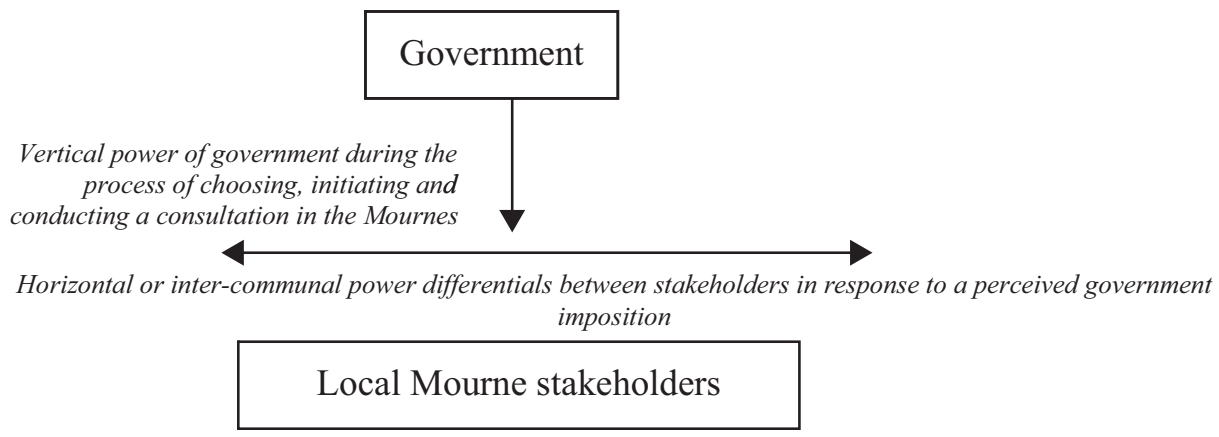

Figure 1: Demonstrating the vertical and horizontal power relations affecting the Mourne national park consultation process.

subsequently generated varying expectations of the consultation process. The working party cited the fact that they were commissioned to 'open up the debate' and report on local views, rather than consult on concrete proposals, as a reason for having a lack of information. Indeed, the consultation was undertaken within a legislative vacuum which meant that the working party was unable to provide an outline of possible national park management structures. This lack of information appears to have critically undermined the consultation, through failing to allay fears within, particularly, the landowning and farming community. These perceived, or possibly at times, irrational or imagined fears [37] were allowed to fester perpetuating a 'fear of the unknown' [37]. Sections of the landowning community maintained their stance of outright opposition, unwilling to engage in constructive dialogue or listen to possible solutions to concerns particularly around access. While the perception that a decision to designate had already been made appears to have been particularly damaging to the consultation, the unwillingness within parts of the community to discuss the issue, suggests that resentment towards a Mourne national park stems from something deeper than those concerns which are typical of many rural areas or national parks in the United Kingdom.

Following completion of the official Mourne National Park consultation period in 2007 it was reported that 'the gap between supporters and critics of the national park seems to be widening' [61]. The notable failures inherent in the MNPWP consultation, and the disillusionment evident in the local community, could undermine future efforts to proceed towards a national park designation. Govan et al. [62] have observed how within a national park context, if a sense of community disempowerment takes root, it can take many years to overcome. Prospects of designating a Mourne national park in the immediate future could therefore be severely hampered, as a result of this initial, seemingly flawed $[37,38,61]$, consultation process. However, the context within which the last consultation was conducted was one of relative economic prosperity. Changing global economic circumstances were cited by one interviewee as a possible catalyst for generating more meaningful engagement from the landowning and farming community. Rather than allow a number of dominant individuals to act on their behalf presenting a front of outright aversion, in light of prolonged economic austerity, previously silent stakeholders may now be more willing to engage constructively in discussions to assess the possible benefits of a national park (interview with Mr Richard McLaughlin). Furthermore, economic considerations were also regarded by $\mathrm{Mr}$ Fox and the NGO representative as a possible motivating factor for politically galvanising the national park debate. Mr Fox commented, 'the current economic climate probably makes it easier for politicians in that they can say look, we're in a bita trouble economy wise, we've a deficit, we've a big public sector based economy, we have to start drawing revenue, the evidence shows that national parks can help 
you bring revenue in, so the Mourne area and the rest of NI need this'. While there was unanimous agreement among interviewees that economic considerations should not be the sole driving force behind designation, there was acknowledgement among those interviewed that if politicians decided to take forth a national park designation in Northern Ireland, it would more than likely be to fulfil an economic agenda. As Mr Fox explained: 'I suppose this is probably my concern, now that government has said it does want to go for national parks in Northern Ireland my feeling is that is based largely on an economic rationale, which is fine ... but I would be a wee bit concerned that it's too much seen as it's a money spinner as opposed to protection'.

\section{CONCLUSION}

This paper has shown that economic considerations are at the core of the national park debate in Northern Ireland. Latest attempts by the devolved administration to attract foreign investment to Northern Ireland are being directly challenged by the current global recession [63]. Public spending cuts, a reduction in the block grant from Westminster and the subsequent requirement to reduce dependency on a bloated public sector will heighten the economic challenges facing the devolved administration [64]. Accordingly, there appears to be growing political awareness of the economic contribution that national parks could make. Tourism has been identified as a potential new growth industry in Northern Ireland with government setting ambitious tourism-related targets [42]. However, as Glasson et al. [65] iterate, tourism is an instigator of change and the potential for rapid growth in Northern Ireland presents both an opportunity and a threat. By drawing on the concept of the tourism resource paradox, this paper has demonstrated how in order to realise the long-term economic potential of this sector, it is vital that growth is managed in a way that is both socially acceptable and environmentally sensitive. This is particularly prevalent in Northern Ireland where the tourism industry is highly dependent on the scenic value of its natural landscapes [43]. The structures associated with a national park offer one mechanism for managing tourism growth while maintaining and enhancing the natural heritage base to secure the longevity of socially acceptable, economically viable and environmentally sensitive tourism in Northern Ireland. While the common perception among interviewees was that government is pursuing national park designation to facilitate regional economic growth, the paper revealed that landowning concerns are also tied up in an economic/financial argument. Landowning fears appear to stem from personal financial concerns over possible restrictions on development opportunities.

This paper highlights the contrasting stakeholder understandings concerning the possible impact of a Mourne national park. Furthermore, the challenge of bringing forward a national park designation in a multi-functional, highly contested landscape, where multiple stakeholders compete for dominance, was reflected by the latest attempt to proceed towards national park designation in Mourne, which was fraught with difficulty and controversy. The challenge of reconciling these competing interests represents a direct threat to securing a sustainable countryside solution for Northern Ireland. While the national park concept has evolved considerably since its inception in the United States, the heterogeneous landscapes of Northern Ireland could represent a step too far for establishing national parks. The paper revealed how landowner opposition appears to stem from something deeper than those concerns which are typical of other UK national park contexts; this area is worthy of further study. It is also perhaps appropriate to explore alternative, potentially less divisive, protected area management solutions for Northern Ireland. However, interviews revealed deep land attachment and a conservative attitude among landowners which opposes any outside influence in the management of private land; so, any form of enhanced management is likely to be opposed.

The paper highlights the ongoing challenge of conducting fully inclusive participatory processes in Northern Ireland as a means for informing policy making. The provision of participative spaces to engage new actors in the governing process allegedly contributes to 'deepening democratic practice' 
[66] and represents a fundamental component of a 'new architecture of democratic practice' (p. 1). As Murray [67] explains: 'Consultation, and the claim to use of the results of consultation to develop policy, is now the norm in government at all its scales of operation' (p54). Indeed, much of the rural governance debate has revolved around a critique relating to the extent to which these new supposedly more democratic approaches to governing society have taken place more in 'rhetoric' than 'reality' [68, 69]. Power relations, which 'pervade any spaces for participation' [66], have the potential to determine the inclusivity of participatory spaces as stakeholder involvement and participation can become constrained by the way power is exercised and manifest throughout the process. While one of the most extensive consultation processes ever carried out in Northern Ireland [48] was conducted to inform the national park debate, it did little to alleviate local and often irrational concerns [37] which reinforced the deep-seated fears of many within the landowning community. Distaste at the way in which the consultation process was initiated and steered (vertical power by government) resulted in local opposition which snowballed into a passionate anti-national park campaign. The vociferous nature of particular elements of the opposition served to intimidate and suppress large sections of the local community (inter-communal intimidation or horizontal power differential). The consultation highlighted a complex set of relations between those that entered the consultation arena as power imbalances served to undermine the democratic integrity of the consultation process. While input from the general public appears to have been suppressed, elements of the business community and sections of the farming community appear to have been intimidated by the actions of a well-organised anti-national park campaign. In accordance with what Cornwall [70] detected, the Mourne consultation demonstrated the ability of these 'new democratic spaces' to 'produce new forms of exclusion' (p. 6).

Significant opposition to the idea of national park still appears to exist within Mourne and the flaws inherent in the consultation process (as identified in this paper) could have lasting consequences in terms of future attempts to bring forward national parks in the locality. As an independent report by nominees of the Mourne Trustees, a major stakeholder grouping in the Mournes, concluded: 'much work and effort will be required to defuse the potentially explosive situation which has been created' [71]. Future steps towards national park designation should be explicitly disassociated from the Mourne National Park consultation. Indeed, government should approach future national park discussions with the utmost transparency and openness, adopting new methods of community engagement, which may go some way to ensuring that future efforts are not mired by the shortcomings of past consultations.

Govan et al. [62] have stated the importance of securing political support for national parks. Prospects of proceeding towards national park designation in Northern Ireland could therefore hinge on the willingness of elected representatives to move the issue forward. History suggests that politicians in Northern Ireland have been hesitant to further the national parks agenda in the face of landowner opposition [36]. However, the national park policy agenda has recently re-emerged on the political radar. A national parks White Paper [72] was published in 2011, detailing proposals to establish a legislative framework for national parks in Northern Ireland. The White Paper provides reassurances to landowners who fear a restrictive model of national park, stating a national park would not be 'anti-development' and would not result in any additional planning restrictions: '...the agenda for building in the countryside has already been set by [a recently introduced rural planning policy] PPS 21 [sustainable development in the countryside]. New national park legislation would not disturb this' [72]. A strong economic emphasis is evident throughout the White Paper. One of the clearest examples of this economic rationale can be detected in the proposed national park aims. Notably, the White Paper lists 'Promotion of sustainable economic and social development of the area's communities' (p. 8) as the first national park aim which contradicts normal convention, demonstrating how the socio-economic imperative is at the forefront of government thinking about the 
role of national parks. Typically, the first listed aim of any national park would be conservationorientated. Recognition of the economic benefits of national park designation appears to be a motivating factor for the current Environment Minister (Alex Attwood) who has repeatedly demonstrated his support for taking forward the national park agenda: 'I am on record as saying that I favour the concept of national parks' [73]. Indeed, Attwood demonstrated his distinct awareness of the economic possibilities 'if we proceed with a national park, it can become an economic driver that will help grow the economy in a sustainable way' [74]. If harnessed correctly, a national park offers a mechanism for managing the tourism resource paradox to achieve socio-economic and environmental goals in tandem.

\section{ACKNOWLEDGEMENTS}

The author is grateful to the Department for Employment and Learning (Northern Ireland) for research study funding and to the reviewers for their helpful feedback.

\section{REFERENCES}

[1] IUCN, Managing conflicts in protected areas, The World Conservation Union: Gland, Switzerland and Cambridge, U.K., 1996.

[2] Child, B., Parks in transition: biodiversity, rural development and the bottom line, Earthscan/ James \& James: London, p. 267, 2004.

[3] IUCN, Guidelines for Applying Protected Area Management Categories, IUCN Gland: Switzerland, 2008.

[4] Benediktsson, K. \& Porvaroardottir, G., Frozen opportunities? Local communities and the establishment of Vatnajokull National Park, Iceland, Mountains of Northern Europe. 'Conservation, Management, People and Nature, ed. D.B.A. Thompson, M.F. Price \& C.A. Galbraith, Scottish Natural Heritage: Edinburgh, p. 335, 2005.

[5] Pimbert, M. \& Pretty, J., Diversity and sustainability in community based conservation. Paper presented at the UNESCO-IIPA regional workshop on Community-based Conservation, February 9-12, 1997; Diversity and sustainability in community based conservation. Available at http://www.iied.org/pubs/pdfs/G01094.pdf: 1997.

[6] Hamin, E.M., The US national park service's partnership parks: collaborative responses to middle landscapes. Land Use Policy, 18(2), pp. 123-135, 2001. doi: http://dx.doi.org/10.1016/ $\underline{\text { S0264-8377(01)00006-0 }}$

[7] Warren, C., Managing Scotland's Environment, Edinburgh University Press: Edinburgh, 2009.

[8] Lister-Kaye, J., The enjoyment and understanding of nature and wildness, Enjoyment and understanding of the natural heritage, ed. M.B. Usher, The Stationary Office: Edinburgh, pp. 3-10, 2001.

[9] Brown, K., Innovations for conservation and development. Geographical Journal, 168(1), pp. 6-17, 2002. doi: http://dx.doi.org/10.1111/1475-4959.00034

[10] WCED, Our Common Future, Oxford University Press: Oxford, 1987.

[11] Barker, A. \& Stockdale, A., Out of the Wilderness? achieving sustainable development within scottish national parks. Journal of Environmental Management, 88(1), pp. 181-193, 2008. doi: http://dx.doi.org/10.1016/j.jenvman.2007.04.007

[12] O'Riordan, T. \& Voisey, H., The Politics of Agenda 21, The Transition to Sustainability: The Politics of Agenda 21, ed. T. O’Riordan, H. Voisey, Earthscan: London, 1998.

[13] Lafferty, W.M. \& Eckerberg, K., The nature and purpose of 'local agenda 21'. From the Earth Summit to Local Agenda 21: working towards sustainable development, eds. W.M. Lafferty, K. Eckerberg, Earthscan: London, p. 1, 1998. 
[14] Ogden, P., Protected landscapes: their role in promoting the sustainable use of agricultural use of land. Parks, 13(2), p. 3, 2003.

[15] Hamin, E.M., Western european approaches to landscape protection: a review of the literature. Journal of Planning literature, 16(3), p. 339, 2002.

[16] Beresford, M. \& Phillips, A., Protected landscapes: a conservation model for the 21st century. The George Wright Forum, 17(1), p. 15, 2000.

[17] Phillips, A., Landscape approaches to national parks and protected areas, National parks and protected areas: Keystones to conservation and sustainable development, eds. J.G. Nelson. \& R. Serafin, Springer: Berlin, p. 31, 1997.

[18] Bishop, K., Green, M. \& Phillips, M. Models of National Parks, Scottish Natural Heritage: Perth, 1998.

[19] The Scottish Parliament, National Parks (Scotland) Act. 2000.

[20] Butler, R.W. \& Boyd, S.W. Tourism and National Parks: Issues and Implications. John Wiley: Chichester, 2000.

[21] Harroy, J.P., Tassi, F., Pratesi, F. \& Humphries, C. National Park's of the World. Orbis publishing: London, 1974.

[22] Spirn, A.W., Constructing nature: the legacy of frederick law Olmsted. Uncommon Ground: Rethinking the Human Place in Nature, ed. W. Cronon, W.W. Norton and Company: New York/ London, p. 91, 1996.

[23] Wall Reinius, S. \& Fredman, P. Protected areas as attractions. Annals of Tourism Research, 34(4), pp. 839-854, 2007. doi: http://dx.doi.org/10.1016/j.annals.2007.03.011

[24] McCool, S., Does wilderness designation lead to increased recreational use?. Journal of Forestry, 83(1), pp. 39-41, 1985.

[25] Fredman, P.L., Hornsten, F. \& Emmelin, L. Increased visitation from national park designation. Current Issues in Tourism, 10(1), pp. 87-95, 2007. doi: http://dx.doi.org/10.2167/cit293.0

[26] McIntyre, N., Jenkins, J. \& Booth, K. Global influences on access: the changing face of access to public conservation lands in New Zealand. Journal of sustainable tourism, 9(5), p. 434, 2001. doi: http://dx.doi.org/10.1080/09669580108667413

[27] Healy, N. \& McDonagh, J. Commodification and conflict: what can the irish approach to protected area management tell us?. Society and Natural Resources, 22(4), pp. 381-391, 2009. doi: http://dx.doi.org/10.1080/08941920801978622

[28] Zimmerer, K.S. The reworking of conservation geographies: non equilibrium landscapes and nature-society hybrids. Annals of the American Association of Geographers, 90(2), pp. 356, 2000. doi: http://dx.doi.org/10.1111/0004-5608.00199

[29] Mbaiwa, J.E., The socio-economic and environmental impacts of tourism development on the Okavango Delta, north-western Botswana. Journal of Arid Environments, 54(2), pp. 447-467, 2003. doi: http://dx.doi.org/10.1006/jare.2002.1101

[30] Plog, S.C., Why destination areas rise and fall in popularity. Cornell Hotel and Restaurant Administration Quarterly, 14(4), pp. 55-58, 1974. doi: http://dx.doi.org/10.1177/ $\underline{001088047401400409}$

[31] Oliveira, J.A.P., Governmental responses to tourism development: three Brazilian case studies. Tourism Management, 24(1), pp. 97-110, 2003. doi: http://dx.doi.org/10.1016/S0261-5177(02) $\underline{00046-8}$

[32] Williams, P.W. \& Ponsford, I.F., Confronting tourism's environmental paradox: transitioning for sustainable tourism. Futures, 41(6), pp. 396-404, 2009. doi: http://dx.doi.org/10.1016/ j.futures.2008.11.019

[33] Redclift, M.R., Sustainable development (1987-2005): an oxymoron comes of age. Horizontes Antropológicos, 12(25), pp. 65-84, 2006. doi: http://dx.doi.org/10.1590/S0104-71832006000100004 
[34] Weaver, D.B., Tourism and the elusive paradigm of sustainable development, A Companion to Tourism, eds. A.A. Lew, C.M. Hall, \& A,M. Williams, Blackwell Publishing: Oxford, pp. 510-524, 2004.

[35] Northern Ireland Planning Advisory Board, The Ulster countryside report, Northern Ireland Planning Advisory Board: Belfast, 1947.

[36] Buchanan, R.H., Landscape. the recreational use of the countryside, Northern Ireland. Environment and Natural Resources, eds. J.G. Cruickshank, \& D.N. Wilcock, The Queen's University of Belfast: Belfast, p. 265, 1982.

[37] Bell, J. \& Stockdale, A. Towards a multi-purpose model for the proposed Mourne national park. Irish Geography, 42(3), p. 293, 2009. doi: http://dx.doi.org/10.1080/00750770903405439

[38] McAreavey, R., Towards a Mourne National Park? Emergent prospects and pitfalls from articulating needs in a local context. Institute of Spatial and Environmental Planning, Queen's University Belfast: Belfast, 2010.

[39] Rowan, E., Merging Collaborative Planning and Environmental Valuation; eliciting preferences for a national park designation in Northern Ireland. Queen's University Belfast: Belfast, 2009.

[40] Deloitte., Research into the financial cost of the Northern Ireland divide. Deloitte: London, 2007.

[41] Northern Ireland Executive. Programme for Government 2008-2011. Northern Ireland Executive: Economic and Policy Unit, 2008.

[42] Department of Enterprise, Trade and Investment. A Draft Tourism Strategy for Northern Ireland to 2020. DETI: Belfast, 2010.

[43] Northern Ireland Environmental Policy Group. National Parks and other Protected Landscape Areas: A discussion of options for establishing national parks and managing other outstanding landscapes in Northern Ireland. Department of the Environment: Belfast, 2004.

[44] Johnson, A., Northern Ireland's national park back in the wilderness, The Independent Media: London, 2009.

[45] Warren, C., The 'natural': conservation management, Managing Scotland's Environment, ed. C. Warren, Edinburgh University Press: Edinburgh, p. 214, 2009.

[46] Mourne Heritage Trust. An Introduction to the Mourne Biodiversity Action Plan - A reflection of Mourne's Rich Natural Heritage. MHT: Newcastle (NI), 2007.

[47] Greer, J. \& Murray, M., A Recreation Strategy for the Mourne Area of Outstanding Natural Beauty. The Sports Council for Northern Ireland: Belfast, 1988.

[48] Mourne National Park Working Party Report to the Minister. Environment and Heritage Service: Belfast, 2007.

[49] Countryside Access \& Activities Network Mourne Area of Outstanding Natural Beauty Access Study. CAAN: Belfast, 2007.

[50] Buchanan, C. and Partners Ltd. Tourism in Mourne: Current and Potential Economic Impact. Author: Belfast, 2006.

[51] Mack, N., Loughry, Y. \& McDonald, K. A Socio-economic Profile of the proposed Mournes National Park. Rural Development Council; Policy and Innovation Research Unit: Belfast, 2006.

[52] Bungay, et al., Special Places Need Special Care. Europarc: 2002.

[53] BBC, National park plan moves closer. 2002; 6th January, 2011Available at: http://news.bbc. co.uk/1/hi/northern_ireland/2282701.stm

[54] Dewar, D., Nesbitt prepares first national park. Planning (weekly journal of the Royal Town Planning Institute) 2002 (4th October, p3). 
[55] Environment and Heritage Service, Shared Horizons: Statement of Policy on Protected Landscapes in Northern Ireland. DoE: Belfast, 2003.

[56] Environment and Heritage Service, A Mourne National Park? Department of the Environment: Northern Ireland, 2004.

[57] Inform Communications Northern Ireland Ltd. Report to the Mourne National Park Working Party on the Outcome of their Public Consultation: 'Your opportunity to have your say'. Inform Communications Ltd.: Belfast, 2007.

[58] Bowcott, O., Planning for the worst, Wednesday 4th October, Guardian Media Group: London, 2006.

[59] McKee, L., Green groups attack Foster over fears of new 'bungalow blight', Tuesday 12th February, Independent News and Media Group: Belfast, 2008.

[60] Bell, J.P.W., A national parkless Northern Ireland: the tourism resource paradox and the implications for sustainability. WIT Transactions on Ecology and the Environment, 12-14th July 2011; eds. C.A. Brebbia, E. Beriatos., WIT Press: Southampton, p. p491, 2011.

[61] Cassidy, M., Community split over national park. 2007; March, 30th, 2010 Available at: http:// news.bbc.co.uk/1/hi/northern_ireland/6388157.stm.

[62] Govan, H., Inglis, A., Pretty, J., Harrison, M. \& Wightman, A., Best Practice in community participation for National Parks. Scottish Natural Heritage: Edinburgh, 1998.

[63] First Trust Bank, Economic Outlook and Business Review. First Trust Bank: Belfast, March 2010.

[64] Northern Ireland Executive, Northern Ireland Executive Economic Strategy: Consultation on priorities for sustainable growth and prosperity. Northern Ireland Executive: Belfast, 2011.

[65] Glasson, J., Godfrey, K. \& Goodey, B. Towards visitor impact management: Visitor impacts, carrying capacity and management responses in Europe's historic towns and cities. Avebury: England, 1995.

[66] Cornwall, A., Making spaces, changing places: situating participation in development. Institute of Development Studies (IDS): Brighton, 2002.

[67] Murray, M., Participatory Rural Planning: Exploring Evidence from Ireland. Ashgate: Surrey, 2010.

[68] Edwards, B., Goodwin, M., Pemberton, S. \& Woods, M., Partnerships, power and scale in rural governance. Environment and Planning C: Government and Policy, 19(2) pp. 289-310, 2001. doi: http://dx.doi.org/10.1068/c12m

[69] Derkzen, P., Franklin, A. \& Bock, B., Examining power struggles as a signifier of successful partnership working: a case study of partnership dynamics. Journal of Rural Studies, 24 pp. 458-466, 2008. doi: http://dx.doi.org/10.1016/j.jrurstud.2008.03.010

[70] Cornwall, A., Introduction: new democratic spaces? the politics and dynamics of institutionalised participation. Institute of Development Studies Bulletin, 2004.

[71] Mourne Trustees, Report on the outcome of the Mourne national park consultation exercise by nominees of the Mourne Trustees. 2010.

[72] Department of the Environment (NI) White Paper on Proposed Enabling Legislation for National Parks. DoE: Belfast, 2011.

[73] Department of the Environment (NI) Consultation document on enabling legislation for national parks. DoE: Belfast, 2011.

[74] County Down Outlook, Park backing, 1st June, Alpha Newspaper Group: Dungannon, 2011. 